CASE REPORT

\title{
Spontaneous Direct Carotid-Cavernous Fistula in an Elderly Patient
}

\author{
Stanimir S. Sirakov' ${ }^{1}$, Borislav D. Kitov ${ }^{2}$, Kristina S. Sirakova ${ }^{1}$, Ivo I. Kehayov ${ }^{2}$ \\ ${ }^{1}$ Department of Radiology, Medical University of Sofia, Sofia, Bulgaria \\ 2 Department of Neurosurgery, Faculty of Medicine, Medical University of Plovdiv, Plovdiv, Bulgaria
}

\section{Correspondence:}

Ivo I. Kehayov, Department of Neurosurgery, Faculty of Medicine, Medical University of Plovdiv, 15A Vassil Aprilov Blvd., 4002 Plovdiv, Bulgaria

E mail:dr.kehayov@gmail.com; dr.kehayov@yahoo.com Tel: +359899105352

Received: 26 Apr 2017

Accepted: 23 May 2017

Published Online: 29 May 2017

Published: 22 Dec 2017

Key words: carotid-cavernous fistula, endovascular treatment, surgery

Citation: Sirakov SS, Kitov BD, Sirakova KS, Kehayov II. Spontaneous direct carotid-cavernous fistula in elderly patient.

Folia Medica 2017;59(4):472-6. doi: 10.1515/folmed-2017-0059
We describe the case of an 83-year-old woman with left-sided ophthalmoplegia. She had no family history of connective tissue disease. The computed tomography study found a dilated left cavernous sinus. The conventional cerebral panangiography confirmed the diagnosis - a direct carotid-cavernous fistula (CCF), with no evidence of ruptured aneurysm. The woman underwent endovascular treatment with coiling of the cavernous sinus in combination with application of the Onyx embolic agent in the fistula. During the first 48 hours after the embolization the local pain, exophthalmos and conjunctival injection of the left eye were significantly ameliorated. The pulsatile tinnitus on the left disappeared and the ptosis of the left eyelid partially recovered.

Selective angiography is the best method for the diagnosis and classification of CCF. Currently, treatment is possible with low mortality and morbidity rates. The endovascular intervention is able to completely occlude the fistula and maintain adequate blood flow through the carotid artery.

\section{INTRODUCTION}

Carotid-cavernous fistulas (CCF) are abnormal shunts which lead to a direct or indirect passage of blood from the internal carotid artery (ICA) into the cavernous sinus (CS). CCF are classified according to their etiology as traumatic or spontaneous; according to the blood flow velocity - as high or low-velocity, and in terms of their angiographic architecture - direct (by the ICA itself) or indirect - by a branch of the ICA or the external carotid artery (ECA). ${ }^{1}$ Barrow et al. define four types (A D) of CCF, depending on the blood supply. ${ }^{2}$ Type $\mathrm{A}$ is the most common $(75-80 \%)$ and is a direct, high-velocity shunt from the ICA to the CS, caused by a lesion of the wall of the artery due to trauma or aneurysmal rupture. ${ }^{1,2} \mathrm{CCF}$ types $\mathrm{B}, \mathrm{C}$ and $\mathrm{D}$ result from an indirect communication between $\mathrm{CS}$ and the meningeal branches of ICA (type B), ECA (type C) or both ICA and ECA (type D). ${ }^{2}$
Spontaneous CCF, which represent about $30 \%$ of all, are more common in elderly patients and are caused by a ruptured intracavernous aneurysm of ICA. ${ }^{3}$ Risk factors for the occurrence of CCF are fibromuscular dysplasia, Ehlers-Danlos syndrome and elastic pseudoxanthoma (Grondblad-Strandberg syndrome). ${ }^{1,4}$ It is believed that the weakness of the arterial walls in these patients predisposes them to the development of CCF even as a result of minimal increase of pressure, such as sneezing or the Valsalva maneuver. ${ }^{1}$ In the absence of aneurysms or other risk factors, it is assumed that a microscopic vein thrombosis may cause a lesion of a dural vessel in the CS leading to the development of CCF, especially in cases with arterial hypertension, atherosclerosis, pregnancy, minor injuries, diabetes and collagen diseases. . $^{1,2,5,6}$

We present a case of successful endovascular embolization of spontaneous direct CCF. 


\section{CASE REPORT}

An 83-year-old woman was admitted to the Clinic of Neurosurgery of St George University Hospital, Plovdiv, Bulgaria after she had experienced a severe sharp pain in the left side of her head during sleep accompanied by vomiting. A pulsatile tinnitus in the left ear occurred. Within 24 hours she developed chemosis and exophthalmos of the left eye with closure of the left eyelids. The patient had no family history of connective tissue disease.

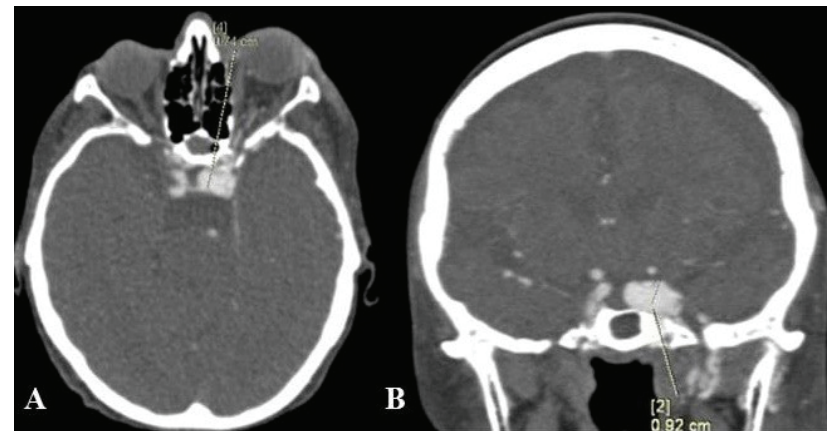

Figure 1. CT with contrast enhancement in the axial (A) and coronal view (B) showed the dilated left cavernous sinus.

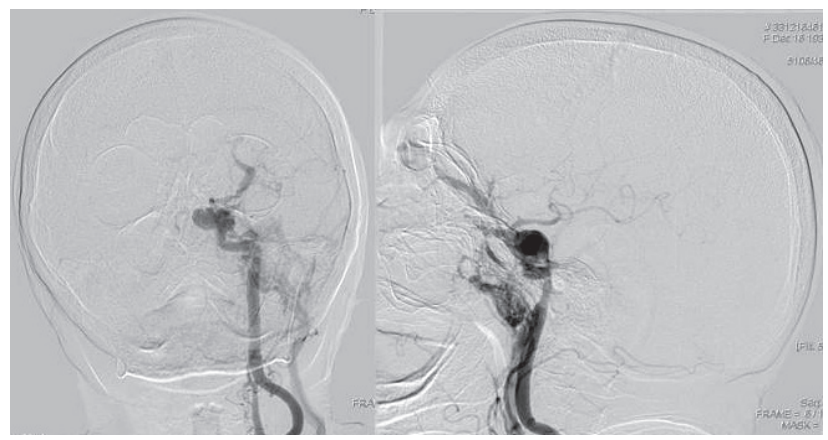

Figure 2. Conventional cerebral DSA - a fistula from the left internal carotid artery.

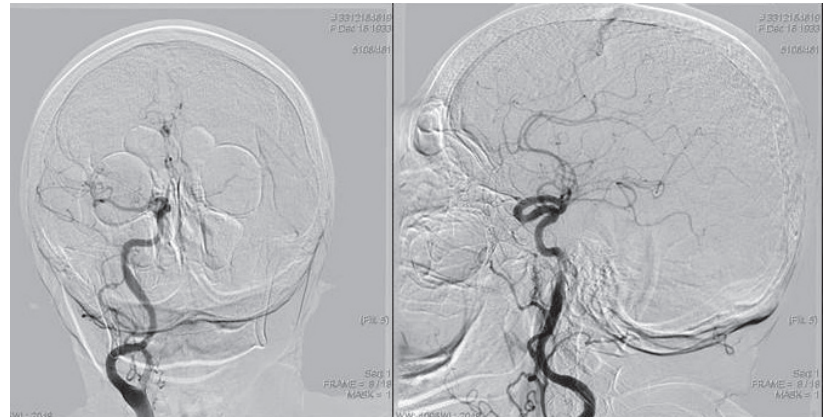

Figure 3. AP and lateral angiogram of the right carotid artery - no fistulas.
The physical examination revealed chemosis and pronounced exophthalmos of the left eye, ptosis of the left eyelid with conjunctival injection. The focal neurological deficit included left-sided ophthalmoplegia.

The initial computed tomography (CT) found no evidence of intracranial hemorrhage, but showed a dilated left cavernous sinus (Fig. 1). Presence of

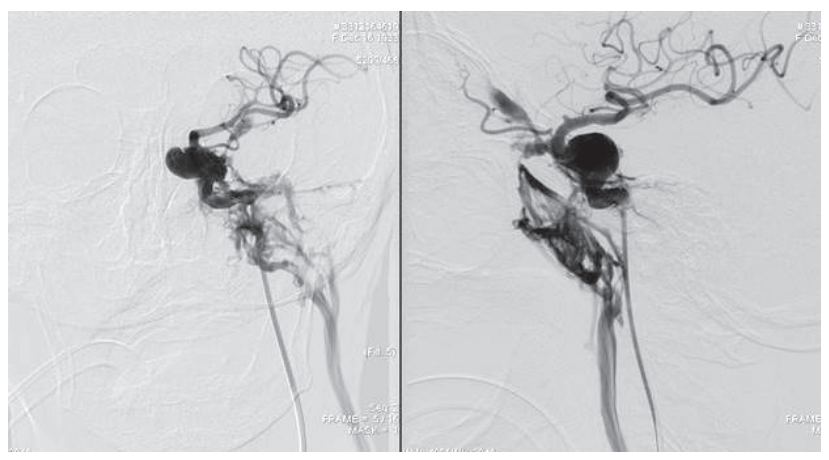

Figure 4. Selective catetherization of the the left internal carotid artery demonstrated carotid-cavernous fistula.

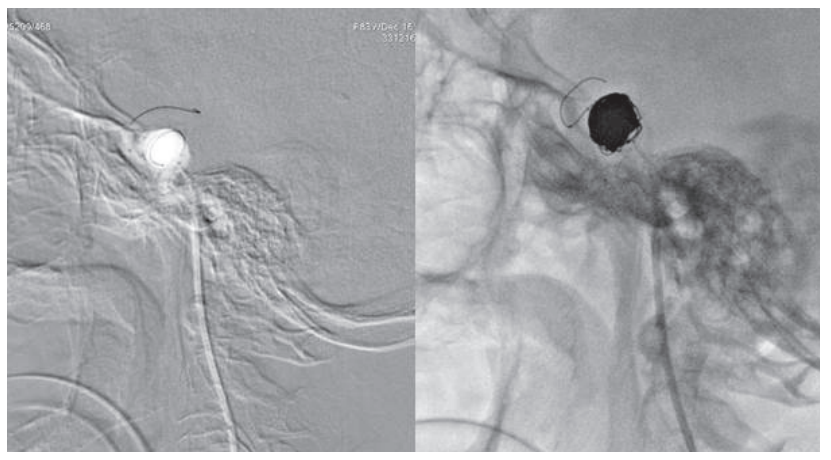

Figure 5. Filling of the fistula with platinum coils under the protection of a balloon in the lumen of the carotid artery.

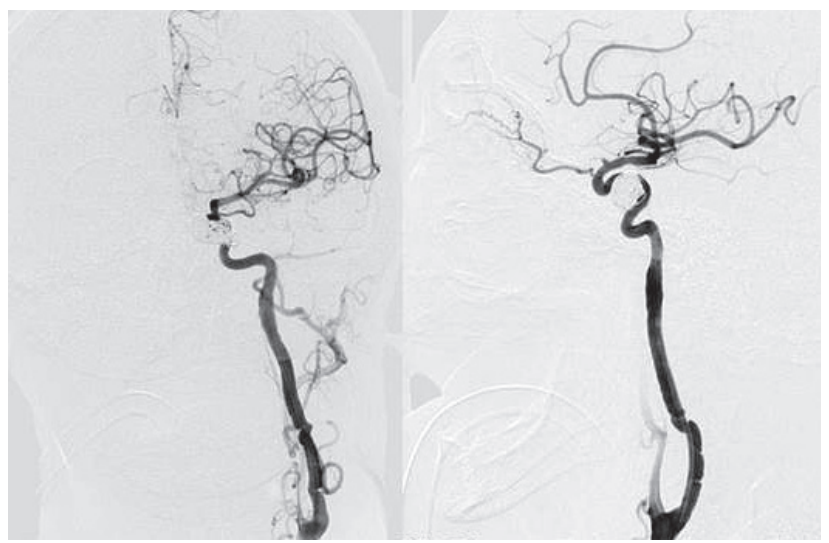

Figure 6. Postprocedural DSA revealed successful embolization of carotid-cavernous fistula. 


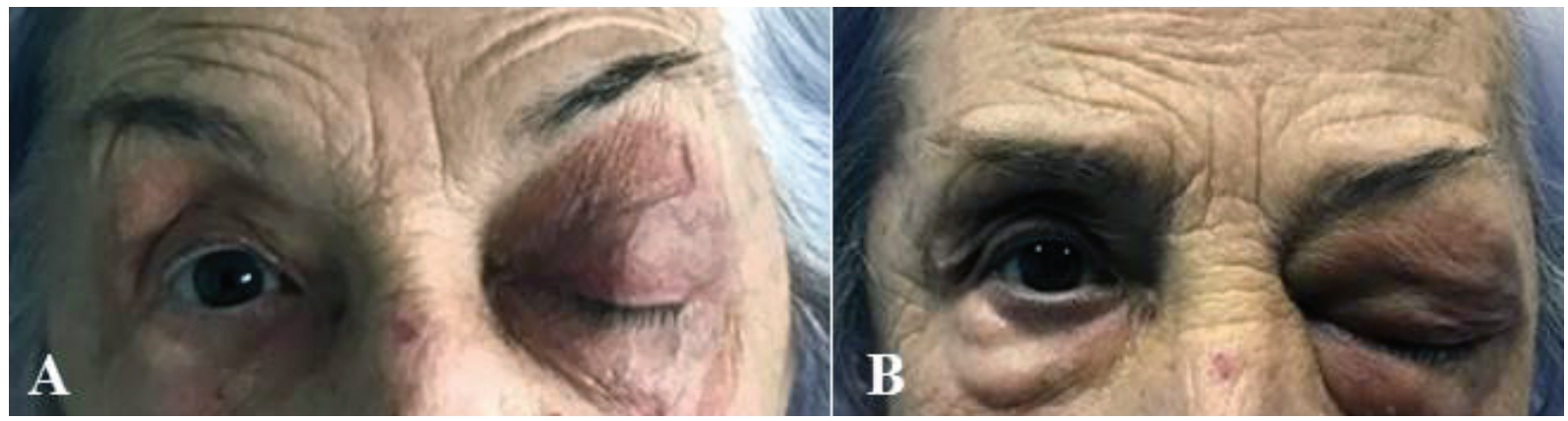

Figure 7. Status of the left eyelid - before (A) and after (B) the embolization.

CCF was suspected. The patient was transferred to St Ivan Rilski University Hospital, Sofia, Bulgaria for endovascular treatment. The conventional cerebral digital subtraction angiography (DSA) confirmed the diagnosis. The early arterial phase demonstrated dilation of the left CS, accompanied by significantly dilated left superior ophthalmic vein and petrosal sinus (Fig. 2). The angiogram of the right ICA did not show the presence of any fistulas (Fig. 3).

Endovascular treatment was performed due to the progressive ophthalmic symptoms and severe headaches. Under general anesthesia, the right femoral artery was catheterized using the Seldinger technique and a 7 french catheter had been advanced through a long introducer in the right femoral artery and the left ICA was reached. A roadmap was made for better navigation during the procedure. Using two microcatheters, the CS was selectively catheterized through the fistula from the left ICA and transvenously through the petrosal sinus on the left (Fig. 4). The lumen of the cavernous sinus was filled with platinum coils through one of the microcatheteres (Fig. 5).

In order to reduce the risk of eventual recanalization of the fistula, Onyx embolic agent was applied through the second transvenous microcatheter, after placing a balloon catheter in the lumen of the left ICA that aimed at protection of unwanted protrusion into the lumen of the latter. A complete filling of the cavernous sinus and exclusion of the fistula from the blood circulation was accomplished (Fig. 6).

During the first 48 hours after the embolization the pain, exophthalmos and conjunctival injection of the left eye significantly improved. The pulsatile tinnitus on the left disappeared, and the movement of left eyelid had partially recovered (Fig. 7).

\section{DISCUSSION}

The relatively rare direct CCF (type A) have an acute onset and rapid progression of the clinical symptoms, which depend not only on the blood flow, but also on the venous drainage of the fistula. ${ }^{1,3,7}$ The age of our patient and the lack of history of previous facial craniocerebral trauma are suggestive of the spontaneous nature of the CCF. The absence of clinical evidence of fibromuscular dysplasia, EhlersDanlos syndrome and elastic pseudoxanthoma suggested the presence of an intracavernous aneurysm, but it was not visualized by neuroimaging. Despite the presence of risk factors in our patient, such as atherosclerotic changes and moderate hypertension, a lesion of a dural vessel in the CS was also omitted due to the presence of a fistula in the left ICA.

The most common initial clinical symptoms of CCF include proptosis (72-98\%), chemosis (55$100 \%)$, headache $(25-84 \%)$ and pulsatile tinnitus (71-80\%). ${ }^{9}, 10$ Subsequently, ocular disorders such as orbital pain, diplopia (88\%) and blurred vision may occur. ${ }^{3,8,9}$ According to Ellis et al., these disorders are caused by ischemia of the retina and require urgent treatment. ${ }^{1}$ Wang et al. share that ophthalmoplegia is observed in $23-63 \%$ of cases, while disturbances in other cranial nerves are less common $(17-44 \%)$, which is confirmed by the clinical presentation observed in our case. ${ }^{9}$

$\mathrm{CT}$ and magnetic resonance angiography can visualize the dilated cavernous sinus and diagnose the CCF. The conventional cerebral DSA is the diagnostic method of choice, which not only do show the presence of an aneurysm in the intracavernous part of ICA, but also visualizes an existing fistula and its drainage.

Emergency interventional therapy is needed in cases of rapidly progressing eye symptoms and/ or impaired cortical venous drainage. The aim of 
CCF treatment is to completely obstruct the fistula and preserve adequate blood flow through the ICA. ${ }^{9,10}$ Currently, the transarterial and transvenous embolization by coils and/or liquid embolic agents is the gold standard in the treatment of CCF. ${ }^{8,9}$ Complications after the endovascular treatment of CCF are observed in $2-5 \%$ of cases and include brain infection, visual disturbances, diabetes insipidus, venous thrombosis, ophthalmoplegia, transient paralysis of cranial nerves and occlusion of the internal carotid artery due to protrusion of coils. ${ }^{10}$

\section{CONCLUSION}

Selective cerebral DSA is the best method for the diagnosis and classification of CCF. Currently, treatment is possible with low mortality and morbidity rates. The endovascular intervention can offer complete occlusion of the fistula with preservation of the normal blood flow through the carotid artery.

\section{REFERENCES}

1. Ellis JA, Goldstein H, Connolly S Jr, et al. Carotid-cavernous fistulas. Neurosurg Focus 2012;32(5):E9:1-11.

2. Barrow DL, Spector RH, IBraun IF, et al. Classification and treatment of spontaneous carotid-cavernous sinus fistulas. J Neurosurg 1985;62:248-56.

3. van Rooij WJ, Sluzewski M, Beute GN. Ruptured cavernous sinus aneurysms causing carotid cavernous fistula: incidence, clinical presentation, treatment, and outcome. AJNR Am J Neuroradiol 2006;27:185-9.

4. Chuman H, Trobe JD, Petty EM, et al. Spontaneous direct carotid-cavernous fistula in Ehlers-Danlos syndrome type IV: two case reports and a review of the literature. J Neuroophthalmol 2002;22:75-81.

5. Ringer AJ, Salud L, Tomsick TA. Carotid cavernous fistulas: anatomy, classification, and treatment. Neurosurg Clin N Am 2005;16:279-95.

6. Wolfe SQ, Cumberbatch NM, Aziz-Sultan MA, et al. Operative approach via the superior ophthalmic vein for the endovascular treatment of carotid cavernous fistulas that fail traditional endovascular access. Neurosurgery 2010; 66(6 Suppl Operative):293-9.

7. Lee RJ, Chen CF, Hsu SW, et al. Cerebellar hemorrhage and subsequent venous infarction followed by incomplete transvenous embolization of dural carotid cavernous fistulas: a rare complication: case report. J Neurosurg 2008;108:1245-8.

8. Gupta AK, Purkayastha S, Krishnamoorthy T, et al. Endovascular treatment of direct carotid cavernous fistulae: a pictorial review. Neuroradiology 2006;48:831-9.

9. Wang W, Li YD, Li MH, et al. Endovascular treatment of post-traumatic direct carotid-cavernous fistulas: A single-center experience. J Clin Neurosci 2011;18:24-8.

10. Fifi JT, Meyers PM, Lavine SD, et al. Complications of modern diagnostic cerebral angiography in an academic medical center. J Vasc Interv Radiol 2009;20:442-7. 


\section{Спонтанная прямая каротидно-кавернозная фистула у пациента пожилого возраста}

\section{Станимир С. Сираков ${ }^{1}$, Борислав Д. Китов ${ }^{2}$, Кристина С. Сиракова ${ }^{1}$, Иво И. Кехайов ${ }^{2}$}

${ }^{1}$ Кафедра радиологии, Медицинский университет - София, София, Болгария

${ }^{2}$ Кафедра нейрохирургии, Медицинский университет - Пловдив, Пловдив, Болгария

\begin{abstract}
Адрес для корресонденции: Иво И. Кехайов, Кафедра нейрохирургии, Медицинский университет - Пловдив, бул. „Васил Априлов“ № 15 А, 4002, Пловдив, Болгария

E mail: dr.kehayov@gmail.com dr.kehayov@yahoo.com

Tel: +359899105352
\end{abstract}

Дата получения: 26 апреля 2017 Дата приемки: 23 мая 2017 Дата онлайн публикации: 29 мая 2017

Дата публикации: 22 декабря 2017

Ключевые слова: каротидно-кавернозная фистула, эндоваскулярное лечение, хирургия

Образец цитирования: Sirakov SS, Kitov BD, Sirakova KS, Kehayov II. Spontaneous direct carotidcavernous fistula in elderly patient. Folia Medica 2017;59(4):472-6. doi: 10.1515/folmed-2017-0059
Предлагаем вашему вниманию случай левосторонней офтальмоплегии у 83-летней женщины. Нет предварительных данных о болезни соединительной ткани. КТ установила расширенный левый кавернозный синус. Конвенциональная церебральная панагиография подтвердила поставленный диагноз - прямая каротидно-кавернальная фистула без наличия разорванной аневризмы.

Была проведена эндоваскулярная терапия с применением койлинга кавернозного синуса в комбинации с применением оникс эмболизирующего агента в фистуле. В течение 48 часов после эмболизации наступило значительное облегчение локальной боли, экзофтальма и конъюктивальной инъекции левого глаза. Пульсирующий шум с левой стороны прекратился и птоз левого века восстановился.

Селективная ангиография является лучшим методом диагностики и идентификации ККФ. В настоящее время лечение возможно с низким уровнем смертности и заболеваемости. Эндоваскулярная интервенция приводит к полному закрытию фистулы и восстановлению нормального кровотока сонной артерии. 